\title{
UTJECAJ FUZIJE SNIMKI NA PROMJENU POVRŠINE ŠUMSKOG PODRUČJA KORISTEĆI NENADZIRANU KLASIFIKACIJU
}

\section{IMAGE FUSION INFLUENCE ON FOREST AREA CHANGE USING UNSUPERVISED CLASSIFICATION}

\author{
Luka RUMORA* ${ }^{*}$, Mario MILER' ${ }^{1}$ Damir MEDAK'
}

\begin{abstract}
Sažetak
Danas su sve traženiji slobodno dostupni satelitski podaci visoke rezolucije poput podataka dobivenih iz Landsat satelitske misije. Karakteristika Landsat podataka je površinska razlučivost snimki od $30 \mathrm{~m}$ x $30 \mathrm{~m}$. Za neke uporabe ta razlučivost nije dovoljna. Landsat satelitska misija, počevši od satelita Landsat 7, prikuplja pankromatski kanal koji služi za povećanje razlučivosti snimki. Ovim radom analiziran je utjecaj fuzije multispektralnih i pankromatskih snimki na promjenu površine šumskog područja koristeći nenadziranu klasifikaciju. Na temelju izvornih snimki izračunat je vegetacijski indeks normalizirane razlike (engl. Normalized difference Vegetation indeks, NDVI) te se takva indeksirana slika koristila kao referentna slika za potrebe daljnje usporedbe. Izvorne snimke prva četiri kanala (plavi, zeleni, crveni i blizu-infracrveni) izoštrene su uporabom osmog (pankromatskog) kanala satelita Landsat 7. Iz tih snimki, na temelju četvrtog (blizu-infracrvenog) i trećeg (crvenog) kanala, izračunat je NDVI. Uz taj postupak provedeno je izoštravanje (fuzija) referentne NDVI snimke. Usporedbom dobivenih slika s referentnom izabrane su slike za klasifikaciju. Nad izabranim slikama provedena je nenadzirana klasifikacija K-means, te je utvrđeno da slika dobivena bikubičnom interpolacijom i izoštravanjem brzom metodom intenzitet-boja-zasićenost (engl. Fast intensity-hue-saturation, FIHS) na temelju prethodno izoštrenih kanala predstavlja najkvalitetnije rješenje.
\end{abstract}

KLJUČNE RIJEČl: fuzija snimki, vegetacijski indeks normalizirane razlike, Landsat 7

\section{UVOD}

\section{INTRODUCTION}

Daljinska istraživanja pronalaze sve veću primjenu u raznim znanstvenim granama. Globalna uporaba metoda daljinskih istraživanja omogućena je podacima prikupljenim satelitskim misijama. Misija Landsat je jedna od najvažnijih satelitskih misija jer su svi prikupljeni podaci slobodni za korištenje bez novčane naknade. Počevši od satelita Landsat 7 1999. godine, moguće je prikupljati i podatke u pankromatskom kanalu. Pankromatski kanal je visokorazlučiv kanal koji, na temelju raznih metoda (npr. Brovey-eva tran- sformacija, Gram-Schmidt-ova, Intenzitet-nijansa-zasićenost (engl. Intensity-hue-saturation IHS), omogućuje poboljšanje razlučivosti multispektralnih kanala (Maglione i sur. 2016). Poboljšanje razlučivosti snimaka na temelju pankromatskog kanala sve se više koristi. Razvojem novih metoda izoštravanja snimaka teži se dobivanju kvalitetnijih snimaka,vizualno sličnih originalu, ali statistički najviše različitih te ubrzanju postupka izoštravanja.

Klasifikacija snimaka provodi se radi lakšeg prepoznavanja objekata na snimkama. Postupak i izbor klasifikacije vrlo su važni prilikom izrade klasificirane snimke. Pogrešan iz-

\footnotetext{
* Luka Rumora, mag. ing. geod. i geoinf., Doc. dr. sc. Mario Miler, Prof. dr. sc. Damir Medak, Sveučilište u Zagrebu, Geodetski fakultet, University of Zagreb, Faculty of Geodesy, Kačićeva 26, HR-10000 Zagreb, lurumora@geof.hr
} 
bor metode ili pogrešno definiran uzorak kod nadzirane klasifikacije mogu dovesti do značajnih pogrešaka u klasifikaciji. Takav postupak povlači za sobom i daljnje pogreške u uporabi tako klasificiranih snimki (Avery i Berlin 1992).

Satelitske snimke s visokom razlučivosti omogućuju istraživanje krajolika na lokalnim i regionalnim razinama. Snimke razlučivosti $<0,5 \mathrm{~m}$ često se koriste za analizu urbanog rasta i razvoja prometa. Multispektralni kanali omogućuju povećanu spektralnu razlučivost koja se može koristiti za daljnje analize i klasifikaciju okolišnih uvjeta, pokrova zemljišta i detekciju promjena te način na koji urbani rast i razvoj prometa utječu na te uvjete (Pellikka i sur. 2004).

Analiza satelitskih snimki služi za brzi, precizni i pouzdani pregled te se često koristi za kvantitativnu procjenu zelene vegetacije i dobivanje karakteristika tla. Metode multispektralne analize snimki koriste različite spektralne odazive raznih objekata (voda, golo tlo, vegetacija, umjetni objekti) u različitim spektralnim kanalima. Različiti objekti posjeduju različite spektralne odazive u različitim kanalima, primjerice tlo ima konstantnu krivulju između različitih kanala, dok vegetacija ima strm uspon između crvenog i blizu infracrvenog (engl. near-infrared, NIR) kanala. Slične karakteristike postoje i kod ostalih objekata, primjerice indikacije, kao što je NDVI (engl. Normalized difference Vegetation Index). Vrijednost refleksije zdrave vegetacije je veća od $50 \%$ u blizu-infracrvenom kanalu, dok je ta refleksija u crvenom kanalu manja od $10 \%$. S druge strane refleksija duboke vode vrlo je loša u vidljivom i blizu infracrvenom spektru (Jones i Vaughan 2010).

Shridhar i Alvarinho (2013) su testirali velik broj algoritama za izoštravanje snimaka na snimkama visoke rezolucije. Uspoređivali su algoritme da bi odredili kako pojedini algoritam statistički i vizualno mijenja satelitsku snimku. $S$ druge strane Johnson (2014) je proučavao utjecaj algoritama za fuziju snimki na vrijednosti vegetacijskog indeksa i zaključio je kako se izoštravanjem vegetacijskih indeksa gubi veliku količinu prostornih podataka.

U ovom radu analiziran je utjecaj metoda fuzije snimki na klasifikaciju. Analizirani su rezultati klasifikacije snimki s naglaskom na promjenu površine svake klase. Hipotezu rada čini pretpostavka da će se obradom satelitskih snimki postojećim metodama fuzije prikupiti nove informacije Cilj rada je usporedba utjecaja metoda fuzije snimki na promjenu rezultata nenadzirane klasifikacije koristeći vegetacijske indekse.

\section{MATERIJALI I METODE MATERIAL AND METHODS}

Za provjeru kvalitete fuzije snimki koristilo se područje šume Česma. Šuma Česma se nalazi u kontinentalnom dijelu Republike Hrvatske u blizini grada Čazme (slika 1).

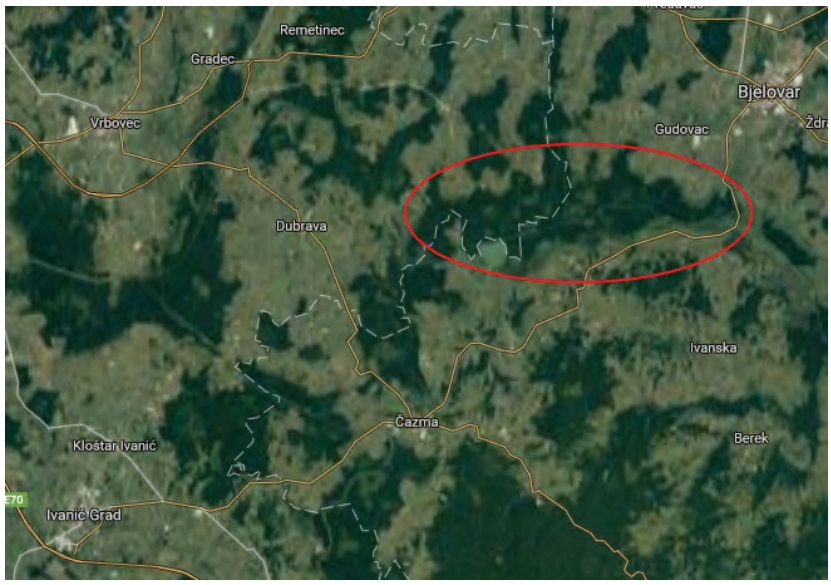

Slika 1: Lokacija šume Česma na Google karti

Picture 1: Forest Česma location on Google maps

Šuma Česma izabrana je spada u zaštićeno područje od 1982. godine i predstavlja posebni rezervat šumske vegetacije. Šuma se prostire na 48,53 ha u kojma se nalaze šumske zajednice hrasta lužnjaka i običnog graba. Prosječna starost šumske zajednice procjenjuje se na oko 130 godina (Vela i sur. 2017).

\section{Landsat 7 - Landsat 7}

Satelitska misija Landsat najdugovječniji je program za prikupljanje satelitskih snimki Zemlje. Započeo je lansiranjem satelita 23. srpnja 1972. Podaci se koriste u agronomiji, kartografiji, geologiji, šumarstvu, regionalnom planiranju, nadzoru i školstvu (Williams i sur. 2006).

Tablica 1: Spektralni kanali Landsat 7 satelita (Williams i sur. 2006) Table 1: Spectral bands of Landsat 7 satellite (Williams et al. 2006)

\begin{tabular}{|c|c|c|c|}
\hline 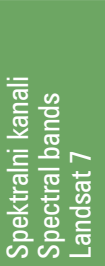 & 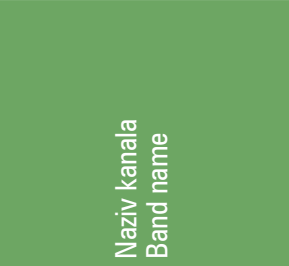 & 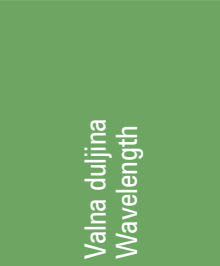 & 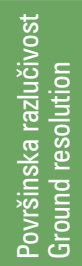 \\
\hline $\begin{array}{l}\text { Kanal } 1 \\
\text { Band } 1\end{array}$ & $\begin{array}{l}\text { plavi } \\
\text { blue }\end{array}$ & $0,45-0,52 \mu \mathrm{m}$ & $30 \mathrm{~m}$ \\
\hline $\begin{array}{l}\text { Kanal } 2 \\
\text { Band } 2\end{array}$ & $\begin{array}{l}\text { zeleni } \\
\text { green }\end{array}$ & $0,52-0,60 \mu \mathrm{m}$ & $30 \mathrm{~m}$ \\
\hline $\begin{array}{l}\text { Kanal } 3 \\
\text { Band } 3\end{array}$ & $\begin{array}{l}\text { crveni } \\
\text { red }\end{array}$ & $0,63-0,69 \mu \mathrm{m}$ & $30 \mathrm{~m}$ \\
\hline $\begin{array}{l}\text { Kanal } 4 \\
\text { Band } 4\end{array}$ & $\begin{array}{c}\text { blizu-infracrveni } \\
\text { near-infrared }\end{array}$ & $0,77-0,90 \mu \mathrm{m}$ & $30 \mathrm{~m}$ \\
\hline $\begin{array}{l}\text { Kanal } 5 \\
\text { Band } 5\end{array}$ & $\begin{array}{c}\text { kratkovalni-infracrveni } 1 \\
\text { short wave-infrared } 1\end{array}$ & $1,55-1,75 \mu \mathrm{m}$ & $30 \mathrm{~m}$ \\
\hline $\begin{array}{l}\text { Kanal } 6 \\
\text { Band } 6\end{array}$ & $\begin{array}{l}\text { termalni } \\
\text { thermal }\end{array}$ & $10,40-12,50 \mu \mathrm{m}$ & $60 \mathrm{~m}$ \\
\hline $\begin{array}{l}\text { Kanal } 7 \\
\text { Band } 7\end{array}$ & $\begin{array}{l}\text { kratkovalni-infracrveni } 2 \\
\text { short wave-infrared } 2\end{array}$ & $2,08-2,35 \mu \mathrm{m}$ & $30 \mathrm{~m}$ \\
\hline $\begin{array}{l}\text { Kanal } 8 \\
\text { Band } 8\end{array}$ & $\begin{array}{l}\text { pankromatski } \\
\text { panchromatic }\end{array}$ & $0,52-0,90 \mu \mathrm{m}$ & $15 \mathrm{~m}$ \\
\hline
\end{tabular}


Landsat 7 lansiran je 15. travnja 1999. Sadrži poboljšani tematski skener (engl. Enhanced Thematic Mapper Plus ETM+). Landsat 7 ima vremensku razlučivost od 16 dana. Sadrži dodatne značajke za globalne primjene, promatranje zemljinog pokrova i kartiranje velikih površina. Sadrži pankromatski kanal s površinskom razlučivosti $15 \mathrm{~m}$ x $15 \mathrm{~m}$, termalni IR kanal s površinskom razlučivosti $60 \mathrm{~m} \mathrm{x} 60 \mathrm{~m}$, multispektralne kanale s površinskom razlučivosti $30 \mathrm{~m} \mathrm{x}$ $30 \mathrm{~m}$.

U postupku obrade satelitskih snimki upotrijebljene su snimke dobivene satelitom Landsat 7. Upotrijebljene su snimke prvog (plavog), drugog (zelenog), trećeg (crvenog) i četvrtog (blizu-infracrvenog) kanala. Upotrijebljen je i osmi (pankromatski) kanal satelita Landsat 7 koji se koristi za potrebe fuzije (izoštravanja) snimki.

\section{Fuzija snimki - Image fusion}

Metode daljinskih istraživanja razvijene su u svrhu identifikacije i isticanja entiteta i objekata. Te metode se primarno oslanjaju na slikovne sustave uporabom senzora s većim brojem spektralnih kanala. Metode fuzije podataka kombiniraju podatke s više senzora i odgovarajuće informacije pripadajuće baze podataka, kako bi se postiglo poboljšanje točnosti i kvalitetniji zaključak od onog do kojeg bi se došlo uporabom samo jednog senzora (Hall i Llinas 1997). Fuzija podataka je proces na više razina (engl. multi level) i više gledišta (engl. multi aspect) koji se koristi automatskom detekcijom, udruživanjem, korelacijom, ocjenom i kombinacijama podataka i informacija od jednog i više izvora (engl. Joint Directors of Laboratories - JDL).

Cilj fuzije snimki konstruiranje je umjetne (hibridne) slike koja će biti što je moguće sličnija stvarnosti. Postupak se bazira na uporabi sinergije informacija koje potječu iz različitih izvora. Umjetna slika treba pružati što je moguće više prostornih informacija te očuvati kvalitetne spektralne informacije. Ako se podaci prikupljeni multispektralnim kanalom jednostavno zamijene podacima prikupljenim pankromatskim kanalom, poboljšat će se prostorna razlučivost, ali s gubitkom prostornih podataka. (Blum i Liu 2005).

Glavni problem analize kvalitete rezultata fuzije slika nedostatak je referentne snimke za kvalitetnu ocjenu. Ne postoji standardizirani postupak ili kriterij za procjenu očekivane koristi pojedine metode ili njenog rezultata. Postupak ocjene trebao bi uspostaviti pravila i kriterije za provjeravanje dvaju svojstava: sličnosti i sinteze (fuzije). Svojstvo sličnosti zahtijeva sličnost između snimke bolje razlučivosti degradirane na snimku lošije razlučivosti i originalne snimke lošije razlučivosti. Svojstvo sinteze kaže da svaka sintetička slika (produkt fuzije) bolje razlučivosti mora biti što sličnija slici koja bi nastala u senzoru na visini leta koja bi osigurala tu bolju razlučivost (Alparone i sur. 2007).
Rezultati fuzije slika vrednuju se na osnovi testova koji se provode u kontekstu procesa fuzije podataka. Kao što je ranije navedeno, postoje različite vrste podataka, kao i metode i razine fuzije tih podataka, čiji su ciljevi vrlo različiti. Iz tog razloga postupci testiranja i vrednovanja će im se bitno razlikovati. Objektivni kriteriji za usporedbu izvorne snimke i pojedinog rezultata fuzije, odnosno za vrednovanje rezultata fuzije slika su (Meng i sur. 2010) koeficijent korelacije, koeficijent regresije, dijagram rasipanja, srednja vrijednost, standardno odstupanje, varijanca i medijan.

$\mathrm{U}$ ovome radu upotrijebljene su dvije vrste fuzije. Metoda fuzije bazirana na supstituciji i fuzija dodavanjem i multiplikacijom (Bretschneider i Kao 2010). Metode fuzije bazirane na supstituciji, temelje se na projiciranju aktualnog prostora boje u drugi prostor te zamjene dobivenih vrijednosti vrijednostima kvalitetnije snimke. U sklopu te metode koristila se brza fuzija intenzitet-boja-zasićenost. Navedena fuzija zamjenjuje skalu boja crvena-zelena-plava (engl. RedGreen-Blue - RGB) sa skalom intenzitet (I), boja (H), zasićenost (S) - IHS. Ta skala se koristi zato što kognitivni sustav ljudi ima tendenciju tretiranja triju komponenti kao približno okomitih osi. Nakon zamjene komponente intenziteta, snimka se transformira u skalu boja RGB. Fuzija dodavanjem i multiplikacijom dodaje ili multiplicira dio pankromatskog signala u multispektralni kanal, čime se postiže visoka korelacija s pankromatskim kanalom. U sklopu te metode upotrijebila se metoda $\mathrm{P}+\mathrm{XS}$ (engl. panchromatic + multispectral). koja se temelji na simultanom prikupljanju pankromatskih i multispektralnih snimki s istim instrumentom. Fuzija se temelji na korelaciji između plavog, zelenog i crvenog kanala s pankromatskim. Metoda mijenja broj piksela kanala dupliciranjem. Nakon fuzije snimki proveden je izračun vegetacijskog indeksa NDVI (Pettorelli i sur. 2005):

$$
N D V I=\frac{\text { blizu infracrven }- \text { crven }}{\text { blizu infracrveni }+ \text { crveni }}
$$

\section{Klasifikacija snimki - Image classification}

Satelitske snimke dobivene daljinskim istraživanjima su multispektralni odziv raznih objekata stoga je teško izravno identificirati željeni element vizualnom interpretacijom. Kako bi bilo moguće razumjeti elemente prisutne na snimci potrebno je klasificirati i zatim poboljšati karakteristike podataka prikupljenih daljinskim istraživanjima. Klasifikacija je proces dodjeljivanja vrijednosti piksela sa snimki, odabranim klasama (Krtalić 2014).

Klasifikacija snimki kompleksan je posao, koji uključuje rigoroznu provjeru testnog uzorka ovisnog o upotrebljenom klasifikacijskom algoritmu. Metode se mogu grupirati u (Weih i Riggan 2010): 
$\Rightarrow$ Nadzirane (polu-automatske) klasifikacijske metode $\Rightarrow$ Nenadzirane (automatske) klasifikacijske metode

$\Rightarrow$ Objektno orijentirane (engl. object-based) klasifikacijske metode.

Nadzirana klasifikacijska metoda je metoda koja predstavlja klasifikaciju određene scene temeljem uzoraka koje je definirao korisnik. Uzorci se koriste kako bi se definirale klase pokrova zemljišta. Klasifikacija se bazira na spektralnim karakteristikama svakog uzorka.

Najpoznatiji algoritmi su maksimalna sličnost (engl. maximum-likelihood) i minimalna udaljenost (engl. minimumdistance) (Weih i Riggan 2010).

Nenadzirana klasifikacijska metoda je metoda koja automatski klasificira scenu na temelju statističkog grupiranja spektralnih značajki i obilježja. Korisnik treba definirati samo broj klasa koje će se kreirati. Najpoznatiji algoritmi su K-means i ISODATA (Krtalić, 2014).

Objektno orijentirana klasifikacijska metoda je metoda koja kreira objekte različitih oblika i veličina, dok metode bazirane na klasifikaciji piksela generiraju kvadrate. Najpoznatija metoda je metoda najbližeg susjeda (engl. nearest neighbor) (Weih i Riggan 2010)..

\section{Parametri kvalitete - Quality parameters}

Izoštravanje snimke ili poboljšanje vizualne kvalitete digitalne snimke može biti subjektivno. Pretpostavka da jedna metoda pruža bolje rezultate od druge može varirati od osobe do osobe. Iz tog razloga potrebno je definirati mjere kvalitete kako bi bilo moguće usporediti utjecaj algoritama za izoštravanje snimke na kvalitetu snimke. Stoga je nakon provedenog postupka fuzije snimki provedena analiza dobivenih podataka. Izračunati su parametri kvalitete programom ORFEO toolbox (Al-Wassai i sur. 2011; Epting 2005; Gwet 2014). Parametri kvalitete su redom srednja kvadratna pogreška (engl. mean squared error - MSE) koja predstavlja mjeru odstupanja pojedinih vrijednosti od srednje vrijednosti, srednja apsolutna pogreška (engl. mean apsolute error - MAE) koja predstavlja razliku između dobivenih i polaznih vrijednosti skupa podataka, odnosno mjeri prosječnu veličinu pogrešaka u dobivenom (ili predviđenom) skupu podataka, vršni omjer signala i šuma (engl. peak signal to noise ratio - PSNR) koji predstavlja odnos između najviše moguće vrijednosti (snage) signala i snage šuma koji utječe na kvalitetu, srednja vrijednost snimki (engl. mean, SVS) koja predstavlja mjeru središnje tendencije diskretnog skupa podataka, ukupna preciznost klasifikacije koja predstavlja omjer ukupnog broja ispravnih piksela (koji se nalaze na dijagonali korelacijske matrice) s ukupnim brojem piksela u korelacijskoj matrici, Kappa koja predstavlja mjeru podudarnosti između klasificirane slike i referentnog skupa podataka, Paersonov koeficijent korelacije koji predstavlja mjeru jakosti linearne veze između dva skupa podataka $u$ rasponu od -1 do 1 , pri čemu visoka korelacija ima vrijednosti između $\pm 0,5 \mathrm{i} \pm 1$, srednja između $\pm 0,3$ i $\pm 0,5$, dok slaba korelacija ima vrijednosti od $\pm 0,1$ do $\pm 0,3$, te standardno odstupanje snimki (STDEV) koje predstavlja mjeru raspršenosti podataka ( preciznost snimke). Što je standardno odstupanje vrijednosti piksela neke snimke veće, to postoji više nijansi sivila koji prikazuju objekte na njoj i snimka je generalno čitljivija.

\section{Tijek obrade - Processing flow}

Izračunat je NDVI vegetacijski indeks na temelju trećeg (crvenog) i četvrtog (blizu-infracrvenog) kanala kao referentna snimka (NDVI_ref). Zatim su izvršene metode fuzije snimki prva četiri kanala i NDVI_ref snimke pomoću snimke osmog kanala satelita Landsat 7. Programom ORFEO Toolbox provedena je bikubična (bicubic) interpolacija snimke i zatim metoda izoštravanja $\mathrm{P}+\mathrm{XS}$ jednostavnim algoritmom RCS (Relative Spectral Contribution). Istim programom je provedena i interpolacija snimke temeljena na najbližem susjedstvu (Nearest Neighbor - NN) i metoda izoštravanja $\mathrm{P}+\mathrm{XS}$ jednostavnim algoritmom RCS. Treći način izoštravanja snimke proveden je skriptom izrađenom programskim jezikom Python. Tom skriptom je definirana bikubična interpolacija snimke, a zatim i brza metoda izoštravanja snimke intenzitet-boja-zasićenost (engl. fast intensity-hue-saturation - FIHS). Sva tri načina fuzije provedena su na multispektralnim kanalima: crveni, zeleni, plavi (RGB) i blizu-infracrveni (NIR); te na NDVI_ref snimci koristeći pankromatski kanal dobiven satelitom Landsat 7. Na temelju izoštravanja NDVI_ref snimke nastale su izoštrene snimke označene NDVI_pansh. Nakon provedene fuzije multispektralnih kanala i pankromatskog kanala za svaki način fuzije snimki izračunao se vegetacijski indeks NDVI (označen NDVI_calc).

Nakon izračuna NDVI vegetacijskih indeksa na temelju izabranih snimaka izvršila se nenadzirana klasifikacija. Za potrebe nenadzirane klasifikacije nisu potrebni uzorci za klasifikaciju. Nenadziranom klasifikacijom promatra se prirodno grupiranje vrijednosti piksela. Zatim se definira prag kako bi se odredio broj klasa na pojedinoj snimci. Nakon grupiranja koristi se poznata vrijednost kako bi se identificirala klasa kojoj pripadaju pikseli. Odabran je klasifikacijski algoritam K-means kako bi se provjerio utjecaj fuzije neovisno o ljudskom faktoru. K-means je popularna metoda nenadzirane klasifikacije. Radi na principu odabira slučajnog uzorka, koji se može smatrati slučajnom vrijednošću. Nakon odabira uzoraka definiraju se linije koje razdvajaju klase. Točke koje se nalaze unutar pojedine klase analiziraju se te se računa njihova sredina. Određene sredine zatim formiraju nove uzorke pri čemu su definirane nove granice klasa. Taj proces se ponavlja nekoliko puta (Krtalić 2014). U ovome radu definirano je 6 klasa radi podjele na šumsku vegetaciju, vodu, izgrađeno područje, obra- 
Tablica 2: Usporedba referentnog crvenog i infracrvenog kanala s izoštrenim crvenim i infracrvenim kanalom Table 2: Comparison between red and infrared band with pansharpened red and infrared band

\begin{tabular}{|c|c|c|c|c|c|c|}
\hline \multirow{3}{*}{$\begin{array}{l}\text { Usporedba } \\
\text { Comparison }\end{array}$} & \multicolumn{3}{|c|}{$\begin{array}{c}\text { Crveni kanal } \\
\text { Red band }\end{array}$} & \multicolumn{3}{|c|}{$\begin{array}{c}\text { Blizu-infracrveni kanal } \\
\text { Near-infrared band }\end{array}$} \\
\hline & $\begin{array}{l}\text { Originalne snimke } \\
\text { i FIHS }\end{array}$ & $\begin{array}{l}\text { Originalne snimke } \\
\text { i bic_RCS }\end{array}$ & $\begin{array}{l}\text { Originalne snimke } \\
\text { i NN_RCS }\end{array}$ & $\begin{array}{l}\text { Originalne snimke } \\
\text { i FIHS }\end{array}$ & $\begin{array}{l}\text { Originalne snimke } \\
\text { i bic_RCS }\end{array}$ & $\begin{array}{c}\text { Originalne snimke } \\
\text { i NN_RCS }\end{array}$ \\
\hline & $\begin{array}{l}\text { Original image } \\
\text { and FIHS }\end{array}$ & $\begin{array}{l}\text { Original image } \\
\text { and bic_RCS }\end{array}$ & $\begin{array}{l}\text { Original image } \\
\text { and NN_RCS }\end{array}$ & $\begin{array}{l}\text { Original image } \\
\text { and FIHS }\end{array}$ & $\begin{array}{l}\text { Original image } \\
\text { and bic_RCS }\end{array}$ & $\begin{array}{l}\text { Original image } \\
\text { and NN_RCS }\end{array}$ \\
\hline MSE & 602,6160 & 504,7760 & 506,8660 & 1225,5300 & 767,5250 & 765,8000 \\
\hline MAE & 20,2771 & 16,6237 & 16,6581 & 27,5942 & 21,1508 & 21,1180 \\
\hline PSNR & 12,7057 & 13,4751 & 13,4572 & 14,0270 & 16,0593 & 16,0691 \\
\hline $\begin{array}{l}\text { Paersonov koeficijent } \\
\text { korelacije } \\
\text { Paerson correlation } \\
\text { coefficient }\end{array}$ & 0,8862 & 0,9870 & 0,9691 & 0,9747 & 0,9703 & 0,9555 \\
\hline
\end{tabular}

Tablica 3 Statistički pokazatelji NDVI slika

Table 3: Statistical indicators of NDVI images

$\begin{array}{ccccccc} & \text { NDVI ref } & \text { NDVI_pansh bic_RCS } & \text { NDVI_pansh NN_RCS } & \text { NDVI_calc bic_RCS } & \text { NDVI_calc NN_RCS } & \text { NDVI_calc FIHS } \\ \text { Min } & -0,3091 & -0,3191 & -0,3258 & -0,3293 & -0,3091 & -0,6452 \\ \text { Max } & 0,7387 & 0,9087 & 0,9054 & 0,7404 & 0,7387 & 0,6471 \\ \text { SVS } & 0,4356 & 0,4334 & 0,4330 & 0,4335 & 0,4333 & 0,3512 \\ \text { STDEV } & 0,2167 & 0,2222 & 0,2231 & 0,2171 & 0,2184 & 0,1746\end{array}$

đeno poljoprivredno zemljište, neobrađeno poljoprivredno zemljište i livadu (ostalo nisko raslinje).

Mogućnost provjere kvalitete klasificiranog podatka je vrlo bitna. Stoga je dodatno izračunat vegetacijski indeks NDVI na temelju izvornih snimki (NDVI_ref) radi usporedbe s vegetacijskim indeksima dobivenim drugim tehnikama. Postupak fuzije snimki proveden je u programu ORFEO Toolbox i na temelju skripte izrađene programskim jezikom Python.

\section{REZULTATI} RESULTS

Rezultati su podijeljeni u dvije cjeline: fuzija snimki i klasifikacija snimki.

\section{Fuzija snimki - Image fusion}

U tablici 2 definirani su statistički pokazatelji razlika između originalne snimke i izoštrene slike kako bi bilo moguće odrediti kvalitetu svake slike.
U tablici 3 prikazani su statistički pokazatelji za referentnu NDVI sliku; slike dobivene računanjem NDVI-a te zatim izoštravanjem (NDVI_pansh); i slike dobivene izoštravanjem kanala te zatim računanjem NDVI-a (NDVI_calc), dok je u tablici 4 prikazana usporedba referentne i izoštrenih NDVI snimki.

\section{Klasifikacija snimki - Image classification}

Nakon provedene fuzije snimki i analize dobivenih rezultata, odlučeno je da će se koristiti: (a) NDVI slika dobivena bikubičnom interpolacijom i izoštravanjem jednostavnom metodom RCS na temelju prethodno izoštrenih kanala, (b) izračunata NDVI slika dobivena interpolacijom NN i izoštravanjem jednostavnom metodom RCS na temelju prethodno izoštrenih kanala, (c) NDVI slika dobivena metodom FIHS.

Klasifikacija je izvršena na referentnoj NDVI slici te na izoštrenim slikama dobivenih fuzijom snimki. U postupku je upotrijebljena nenadzirana klasifikacija K-means. Za ocjenu kvalitete, uz ranije navedene parametre, korištene

Tablica 4 Usporedba referentne NDVI slike s izoštrenim NDVI slikama

Table 4 Comparison of reference NDVI image with pansharpened NDVI images

$\begin{array}{cccccc}\begin{array}{c}\text { Usporedba } \\ \text { Comparison }\end{array} & \begin{array}{c}\text { NDVI_ref i NDVI_pansh } \\ \text { bic_RCS }\end{array} & \begin{array}{c}\text { NDVI_ref i NDVI_pansh } \\ \text { NN_RCS }\end{array} & \begin{array}{c}\text { NDVI_ref i NDVI_calc } \\ \text { bic_RCS }\end{array} & \begin{array}{c}\text { NDVI_ref i NDVI_calc } \\ \text { NN_RCS }\end{array} & \begin{array}{c}\text { NDVI_ref i NDVI_calc } \\ \text { FlHS }\end{array} \\ \text { MSE } & 0,0917 & 0,0920 & 0,0901 & 0,0905 & 0,0760 \\ \text { MAE } & 0,2326 & 0,2328 & 0,2292 & 0,2296 & 0,2236 \\ \text { PSNR } & 10,7796 & 10,7661 & 10,8592 & 10,8382 & 11,5951 \\ \text { PKK } & 0,9929 & 0,9810 & 0,9999 & 0,9797 & 0,9917\end{array}$




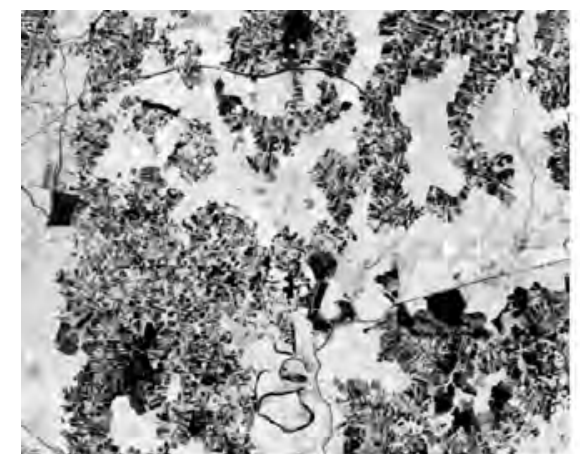

a

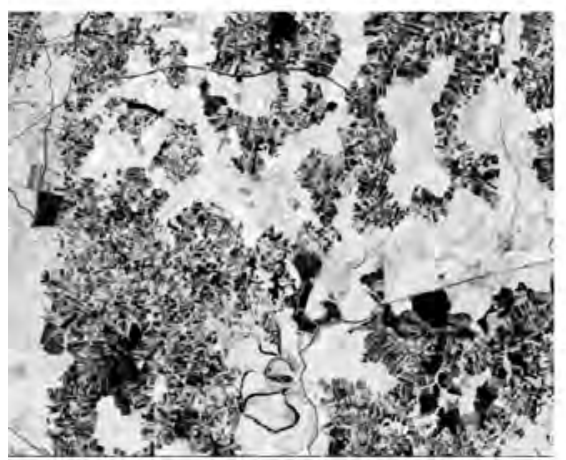

d

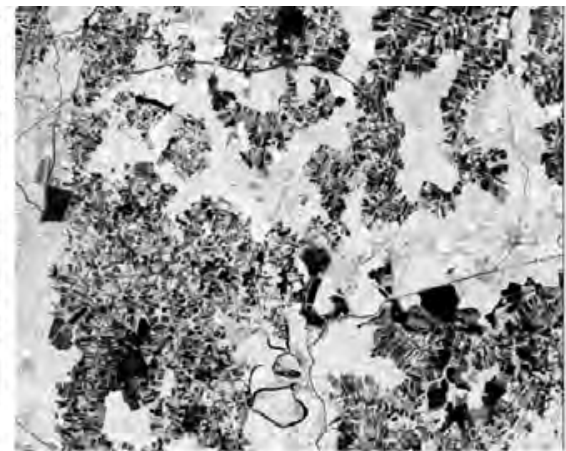

b

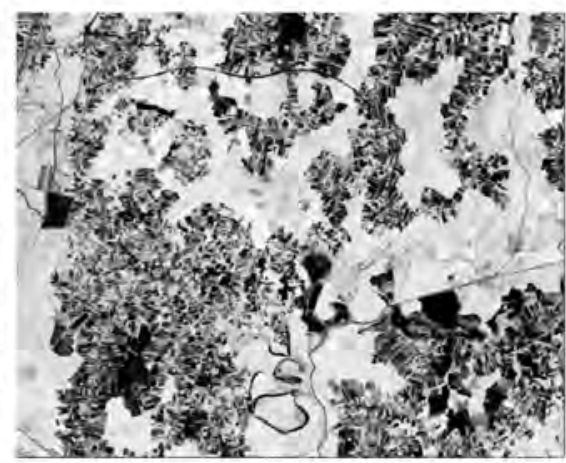

e

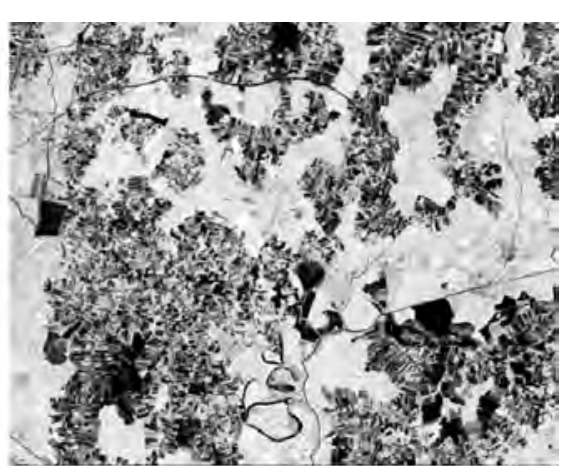

C

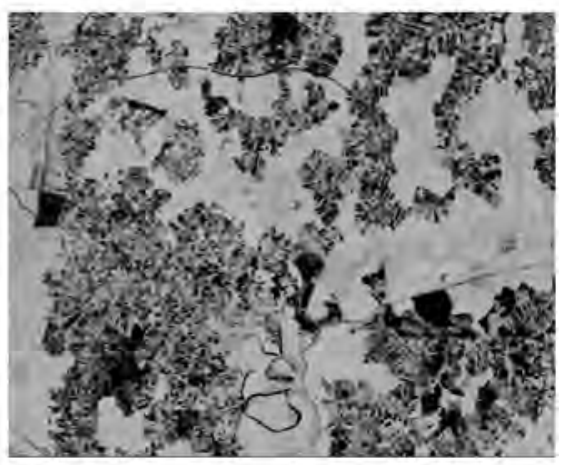

f

Slika 2: a) NDVI referentna slika, b) NDVI_pansh slika dobivena na temelju interpolacije slike NN i metode izoštravanja $P+X S$ jednostavnim algoritmom RCS, c) NDVI_pansh slika dobivena na temelju bikubične interpolacije slike i metode izoštravanja P+XS jednostavnim algoritmom RCS, d) NDVI_calc slika dobivena na temelju interpolacije slike NN i metode izoštravanja P+XS jednostavnim algoritmom RCS e) NDVI_calc slika dobivena na temelju bikubične interpolacije slike i metode izoštravanja P+XS jednostavnim algoritmom RCS, f) NDVI calc slika dobivena na temelju bikubične interpolacije slike i metode izoštravanja FIHS

Picture 2 a) Reference NDVI image, b) NDVI_pansh image calculated using NN image interpolation and P+XS simple RCS pansharpening algorithm, c) NDVI pansh image calculated using bicubic image interpolation and P+XS simple RCS pansharpening algorithm, d) NDVI calc image calculated using NN image interpolation and P+XS simple RCS pansharpening algorithm, e) NDVI_calc image calculated using bicubic image interpolation and P+XS simple RCS pansharpening algorithm, f) NDVI_calc image calculated using bicubic image interpolation and FIHS pansharpening algorithm

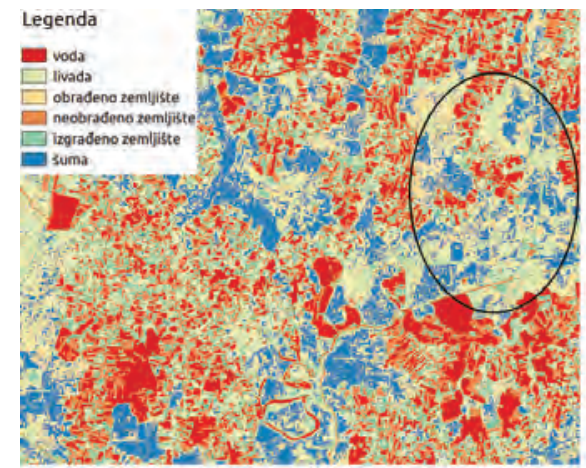

a

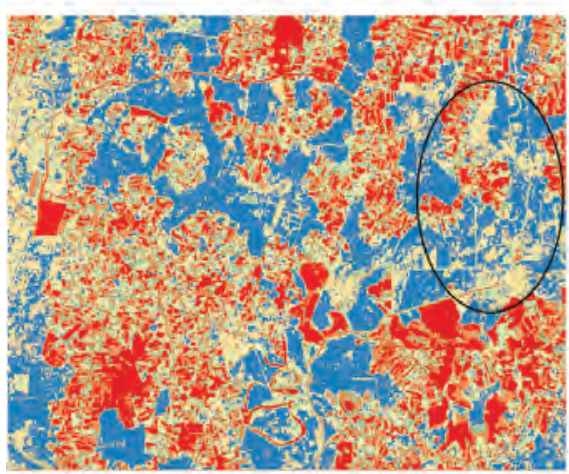

c

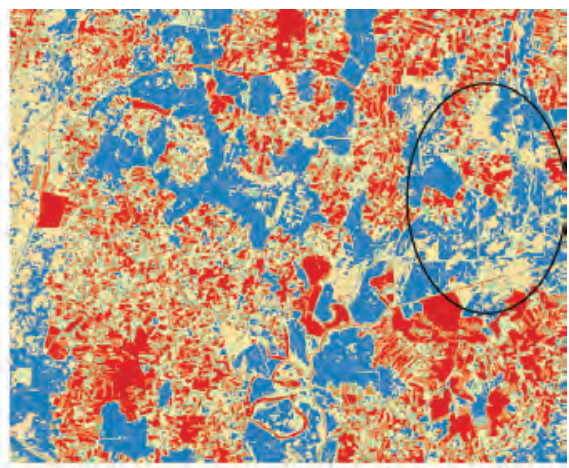

b

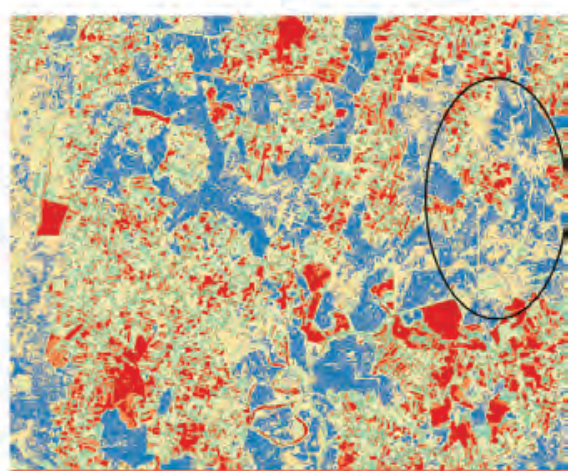

d
Slika 3 a) Klasificirana referentna NDVI slika, b) Klasificirana NDVI calc slika dobivena na temelju bikubične interpolacije slike i metode izoštravanja $\mathrm{P}+\mathrm{XS}$ jednostavnim algoritmom RCS, c) Klasificirana NDVI_calc slika dobivena na temelju interpolacije slike NN i metode izoštravanja $P+X S$ jednostavnim algoritmom RCS, d) Klasificirana NDVI calc slika dobivena na temelju bikubične interpolacije slike i metode izoštravanja FIHS

Picture 3 a) Reference classified NDVI image, b) Classified NDVI_calc image calculated using bicubic image interpolation and $\mathrm{P}+\mathrm{XS}$ simple RCS pansharpening algorithm, c) Classified NDVI calc image calculated using NN image interpolation and P+XS simple RCS pansharpening algorithm, d) Classified NDVI_calc image calculated using bicubic image interpolation and FIHS pansharpening method 
Tablica 5 Usporedba klasificirane referentne NDVI slike s izoštrenim klasificiranim NDVI slikama Table 5 Comparison of reference classified NDVI image with pansharpened classified NDVI images

$\begin{array}{cccc}\text { Usporedba } & \text { NDVI_ref i NDVI_calc bic_RCS } & \text { NDVI_ref i NDVI_calc NN_RCS } & \text { NDVI_ref i NDVI_calc FIHS } \\ \text { Comparison } & 5,3869 & 5,5266 & 5,7704 \\ \text { MSE } & 1,8779 & 1,8800 & 1,9350 \\ \text { MAE } & 6,6661 & 6,5545 & 6,3673 \\ \text { PSNR } & 61,7720 & 64,7434 & 51,5700 \\ \text { Ukupna preciznost - Overall accuracy } & 0,5418 & 0,5774 & 0,4191\end{array}$

Tablica 6 Površina klasificiranih klasa na snimkama

Table 6: Classified area on image

\begin{tabular}{|c|c|c|c|c|}
\hline $\begin{array}{l}\text { Klasa } \\
\text { Class }\end{array}$ & $\begin{array}{c}\text { Originalna snimka } \\
\text { Original image }\left[\mathrm{m}^{2}\right]\end{array}$ & NDVI_calc bic_RCS [m²] & NDVI_calc NN_RCS [m²] & NDVI_calc FIHS $\left[m^{2}\right]$ \\
\hline $\begin{array}{l}0 \text { (voda) } \\
\text { water }\end{array}$ & 47776500 & 51373350 & 50027850 & 30605625 \\
\hline $\begin{array}{c}1 \text { (neobrađeno tlo) } \\
\text { bare soil }\end{array}$ & 53487000 & 53440650 & 57180150 & 39423375 \\
\hline $\begin{array}{l}2 \text { (obrađeno zemljište) } \\
\text { agricultural land }\end{array}$ & 45587700 & 58693050 & 54590625 & 69938100 \\
\hline $\begin{array}{l}3 \text { (livada) } \\
\text { meadow }\end{array}$ & 59705100 & 33698700 & 32040225 & 52077600 \\
\hline $\begin{array}{c}4 \text { (izgrađeno zemlijšte) } \\
\text { urban area }\end{array}$ & 48393000 & 28375875 & 28817325 & 49668975 \\
\hline $\begin{array}{c}5 \text { (šuma) } \\
\text { forest }\end{array}$ & 51813900 & 81181575 & 84107025 & 65049525 \\
\hline $\begin{array}{l}\text { Suma } \\
\text { Sum }\end{array}$ & 306763200 & 306763200 & 306763200 & 306763200 \\
\hline
\end{tabular}

su ukupna preciznost i kappa dobivene iz korelacijske matrice.

Rezultati dobiveni klasifikacijom prikazani su na slici 2. U tablici 5 prikazani su statistički podaci koji ukazuju na sličnost klasificiranih slika s referentnom slikom.

Zatim je izračunat broj piksela u svakoj pojedinoj klasi. $\mathrm{Na}$ temelju navedenih klasa izračunata je površina svake pojedine klase na temelju broja piksela i veličine piksela za svaku sliku. Površina koju Landsat 7 snimka sadrži iznosi $52679.076 \mathrm{~km}^{2}$. Radi jednostavnosti računanja i analize područja oko šume Česma snimka je smanjena, te njena površina iznosi $306.763 \mathrm{~km}^{2}$. Tablica 6 predstavlja površine svake klase na slici ovisno o korištenom algoritmu. Izoštravanjem snimki jednostavnije se određuju granice klasa zbog kvalitetnije rezolucije od 15 metara. Iz tog razloga dolazi do promjene površina u ovisnosti o algoritmu. $\mathrm{Na}$ temelju tih podataka vidljivo je povećanje ili smanjenje površine na slici u odnosu na referentnu. Budući da ne postoji pravilno povećanje ili smanjenje u odnosu na referentnu sliku samo na temelju podataka iz tablice 6 nije moguće zaključiti koja slika predstavlja najviše različitu sliku u odnosu na referentnu.

Usporedba statističkih pokazatelja referentne slike sa svakom pojedinom slikom (tablica 5) pokazala je da se slika dobivena bikubičnom interpolacijom i metodom izoštravanja FIHS na temelju prethodno izoštrenih kanala statistički najviše razlikuje od referentne slike. Vizualnom usporedbom svake slike s referentnom slikom pokazane su međusobne razlike i sličnosti između slika (slika 3). Vizualno najveća sličnost postoji između referentne slike i slike dobivene bikubičnom interpolacijom i metodom izoštravanja FIHS na temelju prethodno izoštrenih kanala.

\section{RASPRAVA DISCUSSION}

U odnosu na dosadašnje radove koji su se većinom bavili analizom utjecaja algoritama za fuziju snimki na vrijednosti vegetacijskog indeksa, ovim radom se dodatno izvršila klasifikacija dobivenih vrijednosti u šest klasa. Klasifikacija se izvršila u šest različitih klasa koje su trebale predstavljati šumu, vodu, izgrađeno područje, obrađeno tlo, neobrađeno tlo i livadu. Kako je vidljivo na slici 2 klase nisu definirane u potpunosti na ovaj način, ali taj rezultat je bio očekivan budući da se radi o nenadziranoj klasifikaciji gdje nije moguće samostalno definirati granice klasa, nego samo broj klasa. Stoga se na slici 2 može vidjeti kako je neobrađeno poljoprivredno tlo svrstano $\mathrm{u}$ istu klasu kao i vodene površine. Zbog spektralnog odaziva šumskog područja koje 
se ističe u odnosu na vodu, izgrađeno zemljište ili neobrađeno zemljište moguće je zajedno s vizualnom analizom, zaključiti da se šuma nalazi u klasi 5 (plava boja). Iz tablice 6 vidljivo je da dolazi do povećanja površine šumskog područja. Povećanje se događa iz razloga što izoštravanjem Landsat 7 satelitske snimke dolazi do promjene prostorne razlučivosti snimke s $30 \mathrm{~m}$ na $15 \mathrm{~m}$, čime je moguće kvalitetnije odrediti granice šumskog područja. Na temelju rezultata klasifikacije izvršila se usporedba površine svake klase te se na temelju dobivenih rezultata izabrala snimka s najviše različitim statističkim pokazateljima, ali vizualno najsličnija.

Na temelju informacija navedenih u prethodnom poglavlju može se zaključiti kao i kod Johnson (2014.), da je slika dobivena bikubičnom interpolacijom i metodom izoštravanja FIHS na temelju prethodno izoštrenih kanala vizualno slična i statistički najviše različita slika. Uzimajući u obzir navedenu tvrdnju kao i cilj fuzije snimki, zaključeno je kako je na temelju slike dobivene bikubičnom interpolacijom i metodom izoštravanja FIHS na temelju prethodno izoštrenih kanala moguće dobiti nove informacije. U ovom radu je zaključeno kao i kod Johnson (2014) kako je potrebno prvo izoštriti kanale satelitskih snimki, a tek tada izračunati vegetacijske indekse.

U ovome radu je također zaključeno kao i kod Shridhar i Alvarinho (2013) kako je vrlo važno odabrati algoritam za fuziju snimki, budući da će statistički kvaliteta snimke ovisiti o odabranom algoritmu.

\section{ZAKLJUČAK}

\section{CONCLUSION}

Usporedbom metoda fuzije snimki pokazano je da postoje jako male razlike između dobivenih slika. Usporedbom NDVI-a dobivenih na više načina zaključeno je kako je potrebno prvo izoštriti satelitske snimke raznih kanala, te zatim izračunati NDVI.

Klasificiranjem izoštrenih slika moguće je, pomoću statističkih pokazatelja i vizualne usporedbe odrediti koja slika zadovoljava tražene uvjete. Vizualno je potrebno da slika bude što sličnija referentnoj, dok s druge strane slika treba biti statistički najmanje slična referentnoj. Uspoređujući slike vizualno (slika 3), statistički na temelju tablice 5 i površinski na temelju tablice 6 , može se zaključiti da slika dobivena bikubičnom interpolacijom i izoštravanjem metodom FIHS na temelju prethodno izoštrenih kanala daje najkvalitetnije rješenje. Tom slikom moguće je dobiti nove podatke, koje je potrebno procijeniti terenskim podacima kako bi se odredila njihova kvaliteta.

Daljnji postupak trebao bi biti promjena metode klasifikacije i prikupljanje podataka s terena da bi se kvalitetnije odredio postupak klasifikacije, kao i uporaba vremenskog niza podataka da bi se mogao usporediti vremenski trend između snimki i terenskih podataka.

ZAHVALA. Ovaj rad financirala je Hrvatska zaklada za znanost projektom AFORENSA I-2389-2015, br. projekta 1924.

\section{LITERATURA REFERENCES}

- Al-Wassai F. A., N. V. Kalyankar, A. A. Al-Zaky, 2011: Studying Satellite Image Quality Based on the Fusion Techniques. International Journal of Advanced Research in Computer Science, Volume 2(5): 354-362.

- Alparone L., L. Wald, J. Chanussot, C. Thomas, P. Gamba, L. M. Bruce, 2007: Comparison of pansharpening algorithms: Outcome of the 2006 GRS-S data-fusion contest. IEEE Transactions on Geoscience and Remote Sensing, 45(10): 3012-3021.

- Avery T. E., G. L. Berlin, 1992: "Fundamentals of remote sensing and airphoto interpretation", Prentice Hall: 1-472, New Jersey

- Bretschneider,T., O. Kao, 2000: Image fusion in remote sensing, In Proceedings of the 1st Online Symposium of Electronic Engineers: $1-8$

- Blum R. S., Z. Liu, 2005: Multi-sensor image fusion and its applications. CRC press: 1-528, Boca Raton

- Epting J., D. Verbyla, B. Sorbel, 2005: Evaluation of remotely sensed indices for assessing burn severity in interior Alaska using Landsat TM and ETM+, Remote Sensing of Environment, 96(3): 328-339.

- Gwet K. L., 2014: Handbook of inter-rater reliability: The definitive guide to measuring the extent of agreement among raters. Advanced Analytics, LLC: 1-428, Gaithersburg

- Hall D., J. Llinas, 1997: An Introduction to Multisensor Data Fusion. Proceedings of the IEEE, Vol. 85(1): 6-23

- Jawak S. D., A. J. Luis, 2013: A comprehensive evaluation of PANsharpening algorithms coupled with resampling methods for image synthesis of very high resolutionremotely sensed satellite data. Advances in Remote Sensing 2013: 332-344

- Johnson B., 2014: Effects of pansharpening on vegetation indices. ISPRS International Journal of Geo-Information, 3(2): 507-522.

- Jones H. G., R. A. Vaughan, 2010: Remote sensing of vegetation: principles, techniques, and applications. Oxford university press: 1-384, New York

- Krtalić A., 2014: Napredna daljinska istraživanja, predavanja, Sveučilište u Zagrebu, Geodetski fakultet, Zagreb

- Meng Q., B. Borders, M. Madden, 2010: High-resolution satellite image fusion using regression kriging, International Journal of Remote Sensing, 31(7): 1857-1876.

- Maglione P., C. Parente, A. Vallario, 2016: Pan-sharpening Worldview-2: IHS, Brovey and Zhang methods in comparison, Int. J. Eng. Technol, 8: 673-679.

- Pellikka P., B. Clark, P. Hurskainen, A. Keskinen, M. Lanne, K. Masalin, P. Nyman-Ghezelbash, T. Sirviö, 2004: Land use change monitoring applying geographic information systems in the Taita Hills, SE-Kenya. In Proceedings of the 5th AARSE Conference: 18-21

- Pettorelli N., J. O. Vik, A. Mysterud, J. M. Gaillard, C. J. Tucker, N. C. Stenseth, 2005: Using the satellite-derived NDVI to assess ecological responses to environmental change, Trends in ecology \& evolution, 20(9): 503-510. 
- Shridhar, D. J. i J. L. Alvarinho, 2013: A comprehensive evaluation of PAN-sharpening algorithms coupled with resampling methods for image synthesis of very high resolution remotely sensed satellite data. Adv. Remote Sens., 2: 332-344.

- Vela, E., I. Medved, V. Miljković, V., 2017: Geostatistička analiza vegetacijskih indeksa na šumskom ekosustavu Česma. Geodetski list, 71(1), 25-40.
- Weih R. C., N. D. Riggan, 2010: Object-based classification vs. pixel-based classification: comparative importance of multi-resolution imagery, The International Archives of the Photogrammetry, Remote Sensing and Spatial Information Sciences, 38(4/ C7): 1-6.

- Williams D. L., S. Goward, T. Arvidson, 2006: Landsat. Photogrammetric Engineering \& Remote Sensing, 72(10): 1171-1178.

\section{Summary}

Demand for high quality free satellite data is increasing. Currently the most popular and known mission is Landsat satellite mission. This mission ensures ground resolution of $30 \mathrm{~m} \times 30 \mathrm{~m}$. For some application, this ground resolution is not sufficient. Landsat mission, starting from the Landsat 7 satellite, collects panchromatic band that is used to increase resolution of images.

This paper analyzes the impact of multispectral and panchromatic image fusion on unsupervised classification. Based on original recordings NDVI (Normalized difference vegetation index) is calculated. This indexed image is used as reference image for the purpose of further comparison. The original images of first four bands (blue, green, red and near-infrared) are sharpened using eighth (panchromatic) band gathered with Landsat 7 satellite. From this bands, based on forth and third band, NDVI is calculated. With this calculation it is conducted pansharpening of reference NDVI image. Images for classification was chosen by comparing obtained images. Selected images was classified with K-means unsupervised classification algorithm, and it was determined that image calculated with bicubic interpolation and sharpened with fast intensity-hue-saturation (FIHS) algorithm on previously sharpened bands represents the best solution.

KEY WORDS: image fusion, normalized difference vegetation index, Landsat 7 